\title{
Food tourism's moment in the New Zealand sun
}

\section{Sarah Meikle}

Sarah Meikle is based at Wellington Culinary Events Trust Inc, Wellington, New Zealand. (c) Sarah Meikle. Published in Journal of Tourism Futures. Published by Emerald Publishing Limited. This article is published under the Creative Commons Attribution (CC BY 4.0) licence. Anyone may reproduce, distribute, translate and create derivative works of this article (for both commercial and non-commercial purposes), subject to full attribution to the original publication and authors. The full terms of this licence may be seen at http://creativecommons. org/licences/by/4.0/legalcode

\begin{abstract}
Purpose - The purpose of this paper is to consider the potential of food tourism to connect local communities and strengthen the visitor economy through COVID-19 induced international visitor downfalls and reimagine New Zealand tourism.

Design/methodology/approach - As a viewpoint paper, this paper is a personal and professional reflection of the relevance of food for New Zealand tourism.

Findings - The three themes of community, connection and challenges identify the potential of using local communities as ambassadors to connect both local and international visitors alike with New Zealand culture.

Practical implications - Findings of this paper can provide guidance for global communities on how to both mitigate a reduction in visitor arrivals while creating a foundation for future positioning as food destinations.

Originality/value - There is a lack of insight into the potential of special interest tourism in reimagining a post-COVID-19 tourism landscape, and this viewpoint paper contributes through its practical and community-based approach.
\end{abstract}

Keywords Food tourism, Hotel, Gastronomy

Paper type Viewpoint

Wellington, New Zealand is a small, but very special capital city at the edge of the world. For years, we were often defined by the "tyranny of distance", sitting at the edge of the Pacific. "It takes a day to get there" was often touted as the reason not to make the journey. But as we enter 2021, after the life-changing year of 2020 and our new world of "COVID-19 normal", being far away no longer seems all that bad. In fact, it feels a bit of a blessing.

The Wellington Culinary Events Trust (WCET), a not-for-profit charitable trust, was established in February 2014, to promote Wellington (city and region) as the premium New Zealand destination for hospitality experiences, thereby adding value to the Wellington region for the benefit of the public of Wellington region.

The culinary and hospitality community provide a critical component of Wellington's cultural offering. WCET's role is to champion this by providing experiences throughout the year, working with a wide range of partners, from community events through to festivals such as Visa Wellington On a Plate (Visa WOAP).

The ultimate goal of the WCET is for the Wellington region to be recognised as the Culinary Capital of New Zealand - raising awareness and growing confidence in the wider Wellington region's food community and to act as a platform for a delicious and diverse range of events, programmes and competitions, accessible to all levels of the community.

Tourism is significant business in New Zealand and, up until the advent of COVID-19, generated up to $21 \%$ of gross domestic product (Tourism New Zealand, 2019). Following the outbreak of COVID-19, New Zealand's borders have been closed to most international visitors since March 2020, which has had a considerable impact on New Zealand's tourism sector. 
Prior to COVID-19, international visitors contributed \$17.2bn each year towards New Zealand's economy, making tourism New Zealand's number one export earner. In addition to this, domestic visitation contributed $\$ 23.7 \mathrm{bn}$. The recovery of New Zealand's international visitor economy will be an important part of New Zealand's overall economic recovery.

Back in March 2020, I do not think anyone could have quite predicted where we would be now. In fact, as we went into lockdown, we had literally just finished the first round of Visa Wellington On a Plate programme curation and were working with festival event and platform participants to refine their applications. And then, bam! Everything came to a grinding halt. But we have come through, and yes, there is still a role for food festivals in this new world.

But this period has also been a bit of a reflective one. At the risk of sounding a bit clichéd, I am a big believer in opportunity coming out of adversity, and I do believe that, right now, New Zealand has an amazing opportunity to really harness food tourism.

Although we were all hunkered down, educating ourselves on the delights of making sourdough bread, and the thrill of discovering our local brewery was delivering beer as an "essential service", there seemed to be somewhat of a dawning for many people: an appreciation of what was available right here in little old New Zealand. And as we have come out on the other side of our long lockdown, there has been a groundswell in support for platforms such as Facebook groups endorsing "buy New Zealand made". Finally, we may have reached the moment where our passion and love for New Zealand has outweighed tireless cultural cringe and an insatiable demand for all things imported or to emulate the food of other destinations. This was the moment we realised that we actually have the best in the world, right here in New Zealand.

Food is a major part of what defines us as Kiwis. But it does not get the same attention as other New Zealand cultural icons such as bungee jumping, rugby or even Crowded House. Food should be one of our great cultural markers as a nation, just as it is for other countries known for their cuisine, such as France or Italy.

In New Zealand, food is intimately woven into our cultural identity - an integral part of what defines us as uniquely Kiwi. Food experiences are a connecter; they are a community-builder; they are a creator of shared experiences and of memories. Food and hospitality are not just about sustenance. For many, it is actually about entertainment and learning; it is about our manaakitanga [1]. New Zealand's hospitality is core to our culture and who we are.

Although there is much discussion around "what is Kiwi food", our food story is not simple to define. When the first European settlers arrived in New Zealand, rather than being influenced by indigenous cuisine, they looked back to the British "motherland" for culinary inspiration - thus fish and chips, the Sunday roast and meat pies became pillars of what we define as "iconic Kiwi food".

Now, as a result of well over a century of immigration and our proximity to the Pacific and Asia, we have embraced the distinctive cuisines of many other countries, along with elements of our own indigenous Māori cuisine. These multiple influences mean New Zealand does not have a singular culinary cultural reference. On the contrary, our multiple ethnic influences together with the wealth of ingredients - fish, meat, fruit and vegetables now produced here, have created an incredibly vibrant and innovative food culture.

New Zealand most certainly has a food story although this is the youngest country on earth, and our food culture in still evolving. It is about embracing our turangawaewae, our place in the world, and about having confidence in ourselves in New Zealand and what we produce. Above all, it is our connection to and understanding of our land as kaitiakitanga - looking at the land not as it owner but as its guardian, as in Māori tradition.

The harvest of our land, waterways and oceans - whether it be indigenous or originally from another part of the globe - is the best in the world. We have learned not to mess around with quality ingredients. Our food style does not masquerade one thing as another - it respects 
the core ingredients, elevating them to another level. Contemporary Kiwi cuisine is about embracing the new without rejecting the old, and it fuses multiple ethnic influences to create new flavour combinations.

This is New Zealand food's moment in the sun. Our audience is literally captive. There is no more time to wait; we need to nail this and nail it now.

\section{What is food tourism?}

In its broadest sense, food tourism is any experience where a consumer can have a taste or "taste of place" of a product or ingredient, which reflects the characteristics (the terroir) of a destination. By this, I mean the ingredients reflecting the lands, lakes, rivers, oceans and skies of a destination, as well as how that is interpreted, either through an agritourism experience, a pick-your-own operation, right through to a farmer's market, food trucks, fine dining restaurants or an attraction that has a food and beverage offering, such as a food festival, food event or culinary tour. Food tourism is where food connects us all and where we come together to really understand a destination's community, its society and culture.

This is important because it contributes to the intangible heritage of a destination and is a unique point of difference from other places - no two destinations are the same when it comes to food. It also attracts visitors who spend more and spread benefits across the whole value chain. Food Tourism is a great economic development driver for lesser visited destinations and communities and can help small-scale producers diversify their product range and revenue opportunities. It also helps visitors connect emotionally to a region and creates lasting visitor loyalty to the place and the products produced. And probably most significantly, food tourism is widely accessible. Food tourism is not just for "foodies", it is for everyone.

The reason I wanted to share this broad definition is to emphasise that food tourism is everywhere, and we experience elements of it almost every day. For the most-part, almost every New Zealander, at some time or another, is a food tourist.

\section{Considerations}

There are big issues everywhere around food and the food system, with things such as sustainability, food resilience, food security and many other like-minded topics dominating the culinary discussion. This paper does not attempt to address or solve these issues but will focus on "food tourism" and specific opportunities and challenges we have.

\section{Community}

That is us - New Zealanders as consumers of food tourism. In my day job, I think about food tourism every moment. When we established Visa Wellington On a Plate, we set a bold vision for Wellington: we wanted Wellington to be New Zealand's most globally recognised food destination. We wanted to create world class culinary experiences in Wellington, focussing on pushing gastronomic boundaries and to be recognised for delivering the most original and innovative culinary events and festivals in the Oceania region. We wanted to set a global benchmark. We were, and still are, squarely focussed on the culinary tourism experience.

Visa Wellington On a Plate was initially developed in 2009 as a joint venture by myself, when I was working for our regional tourism organisation in partnership with our regional economic development agency to solve some very real issues in Wellington. We were dragging our heals through the end of the Global Financial Crisis, and the winter months were positively dire - accommodation and restaurants were really struggling. Not only that, but there was also little opportunity for the wider food and beverage-producing industry to connect with one another. 
Now in 2021 we all see ourselves facing a similar scenario: food tourism is a way to reactivate communities through food - that is your local hospitality and restaurant operators, local producers and suppliers and all the operators down the value chain.

The tourism sector has experienced the most profound shift in focus ever. From a tourism economy reliant on the spend of international visitors, now its focus is 100\% (for at least the foreseeable future) on the domestic visitor. And it is fair to say the motivators for domestic visitors are quite different. Traditionally, aside from business travel, domestic visitors travel for two key reasons:

1. visiting friends and relatives - it is Aunt Carol's birthday, your cousin's wedding or a girls' weekend. Your motivation is often the people before the place, but almost always, the occasion centres around a meal or a food moment; and

2. the other main reason is an event - running a marathon, school holidays, a concert or, dare I suggest, a food festival.

It is a real change in thinking for New Zealanders to start consuming New Zealand as a pure leisure destination. Currently, we are not competing with that trip to India or Japan or Alaska. We are all on offer, and New Zealanders need to view New Zealand through a different lens. What we know through the traditional domestic visitor is that food experiences form a key part of what they do, as these experiences are widely accessible and so many already define a place. We visit local farmers markets, wineries, restaurants and breweries or just soak up a location as we enjoy fish and chips on the beach.

This is food tourism, and all communities can benefit. Food tourism offers great economic development opportunities for lesser visited destinations and communities, and it supports small-scale producers. This is where the rubber hits the road. What we need to be doing, right now, is developing this opportunity - mobilising communities around New Zealand that are part of our food story and telling people about what is on offer.

\section{Connection}

Connection is about the long game. Our borders will not be shut forever, but while they are, let us get busy.

A Wellington food business, Fix \& Fogg Peanut Butter, started stocking the Central Market supermarket in Texas in April 2020. You can also buy Lewis Road Creamery Butter there too. Now, before you think I am going to tell you that going to the supermarket is a food tourism experience, stop right there (although visiting the gourmet supermarket, Moore Wilson's in Wellington is, to many). I want to address this connection between tourism and trade.

For people who have visited New Zealand (or in the domestic case, another region of New Zealand), being able to access our products at their local supermarket is about creating a lasting connection with New Zealand or a region. Not everybody who visits New Zealand will go home and buy a superyacht. Do not get me wrong - I am aware of the importance of some of these high value industries to New Zealand, but we can create a lasting emotional connection with every single visitor to and around New Zealand through food.

Buying Whittaker's Chocolate at Sainsbury's in London or Garage Project beer at Dan Murphy's in Sydney are examples of just this. These products tell a story of a sophisticated food-producing nation that reflects a modern New Zealand. They also create a lasting visitor loyalty to New Zealand and the products produced here.

Connection is also about leveraging our relationships right around the world - New Zealand and its reputation with international chefs and food personalities. During May 2020, highly accoladed and admired chef, Massimo Bottura of Italy, espoused the virtues of New Zealand lamb, salmon, wine and more on an episode of his Kitchen Quarantine on InstaTV. $\mathrm{He}$ is helping us do our job. He is never been here and is motivated, similar to many, to visit 
because of our superb ingredients. We need a stronger connection between New Zealand trade and tourism, and this moment in time marks an opportunity as New Zealand is likely to become an even more desirable destination in the long term.

Of the limited International Visitor research in the food space, it indicates that visitors have very little knowledge or expectation of their New Zealand food experience outside of the traditional messaging around butter, Sauvignon Blanc and green lipped mussels, etc.

In 2018, the Ministry of Primary Industries, together with ANZ Bank, commissioned the New Zealand Food \& Agri Tourism Industry Insights Report [2] that found:

- $83 \%$ of travellers surveyed agreed that seeing food, beverages or restaurants at home reminded them of trips they had previously taken;

- $60 \%$ of travellers purchase food and drinks they first encountered during their travels at home;

- Over $57 \%$ of all tourists surveyed specified "Eating the local/regional food or drink" as a culinary motivator to travel;

- $50 \%$ - the additional amount a foodie tourist spends on food and beverage per day when travelling compared with other leisure tourists;

- 1.9 - international trips per year by foodie tourists compared to 1.5 for non-foodie tourists; and

- $52 \%$ - percentage of generation $X$ and millennial respondents who are foodie tourists.

\section{What New Zealanders are looking for on holiday (September-October 2020) [3]}

The Domestic Travel View quarterly research released by Tourism New Zealand in November 2020 indicates what New Zealanders are looking for on holiday. "Good local food \& beverage experiences" rank as the fifth most important consideration behind relaxation, natural scenery, location and accommodation options (Figure 1).

\section{New Zealand does have food story}

We are the youngest country on earth. Our relatively very recent history means our food culture in still evolving. The challenge is for New Zealanders to understand and embrace our food culture. It is not just about pavlova, pineapple lumps or jaffas. No, our food culture runs deeper than that. It is about our terroir (and not just land that produces fabulous wine); it is about embracing our turangawaewae [4], our place in the world and about having confidence in ourselves, in New Zealand and what we produce.

Above all it is our connection to, and understanding of, our land. Kaitiakitanga looking at the land not as owners but as guardians. Not as separate from the land, but

Figure 1 Aspect New Zealanders are looking for in the New Zealand holiday location (\% NZers planning a holiday, Sep-Oct 20)

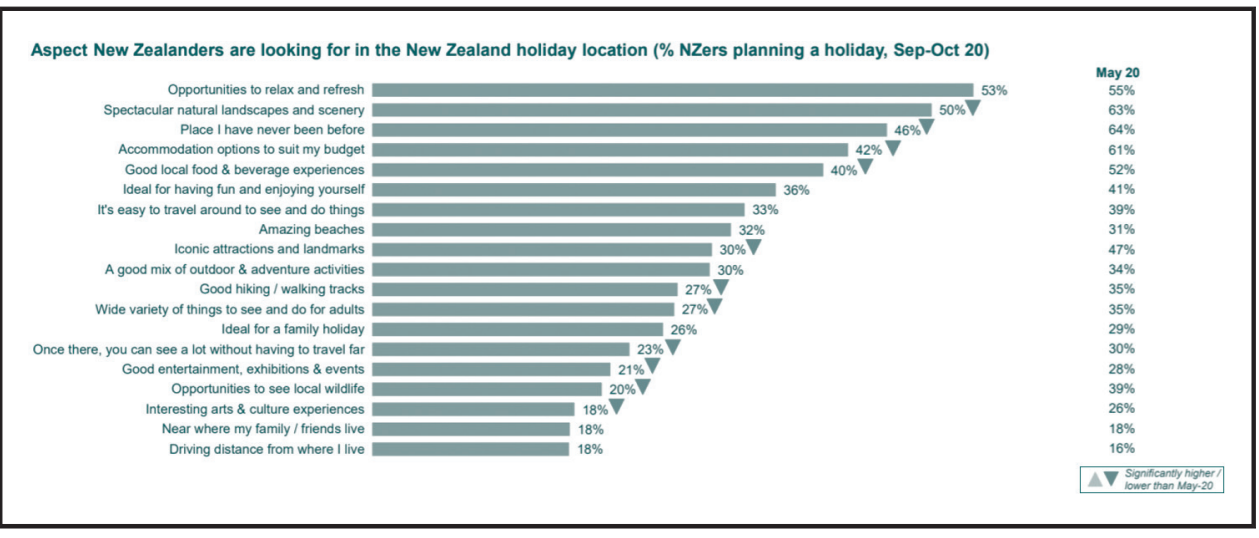


part of it. It is about our people who produce and grow the food, in this place: Aotearoa New Zealand.

It is partly because of that connection to our land, sea, lakes and rivers, that our produce is world-class. Our incredible kaimoana [5], our grass-fed beef, the best lamb in the world both farmed and wild venison - and of course, our superb dairy, apples, hops, grapes, olive oils, peanut butter and chocolate! When you have these kinds of quality ingredients, we have learned not to mess around with them. Our food style doesn't masquerade one thing as another - it respects the core ingredients, elevating them to another level.

Our Māori culinary traditions also play a major part in what defines our distinct culinary culture. Methods of cooking such as hāngi and use of indigenous ingredients such as horopito, kawakawa and mānuka are all unique to us. But why are these herbs not as readily available as cumin, cinnamon, oregano or thyme in our local supermarkets?

Our respect and understanding of where our ingredients come from, who grows them, our combined cultural references of New Zealand, Europe and Asia, and, on top of all of that, some very clever and risk-taking chefs - that is when the various elements of our food story come together.

New Zealand produces the world's best ingredients, in the best land by the most passionate and committed farmers, growers and makers. This is our food story: food grown and made with respect for the land, but by people who genuinely care. Right now is the moment we need all New Zealanders to realise this.

So, to answer the question What role will food play in the reimagination of New Zealand tourism, post-COVID-19? No one loves New Zealand, our food and food experiences more than New Zealanders; they are the most patriotic ambassadors we have. So, it is time to harness that love, enthusiasm and manaakitanga New Zealanders possess for our food and country and use them to help share our story with the world.

We need to be proud of New Zealand's food and beverages. Celebrate them, support them, consume them and make them truly ours. We need to appreciate truly indigenous New Zealand ingredients and tell everyone, everywhere, all the time, just how good it really is. And then, we just might find we start appreciating what a fabulous food culture New Zealand really has, how proud we are of it and realise that, in fact, we can be the world's greatest food tourism destination.

\section{Notes}

1. The word "manaakitanga" does get bandied around a bit. Its true meaning is much more than just the word and its link to "hospitality"; manaakitanga "is a feeling that people get when they come to New Zealand and they should never forget" (Rewi Spraggon, The Hāngi Master, Auckland).

2. www.mpi.govt.nz/news/media-releases/report-shows-opportunities-to-leverage-food-and-beverageexports-with-tourism/

3. www.tourismnewzealand.com/media/4275/domestic-travel-view-report-oct-20.pdf

4. A sense of identity and independence associated with having a particular home base.

5. Food from the sea.

\section{Corresponding author}

Sarah Meikle can be contacted at: sarah@wellingtononaplate.com

For instructions on how to order reprints of this article, please visit our website: www.emeraldgrouppublishing.com/licensing/reprints.htm

Or contact us for further details: permissions@emeraldinsight.com 